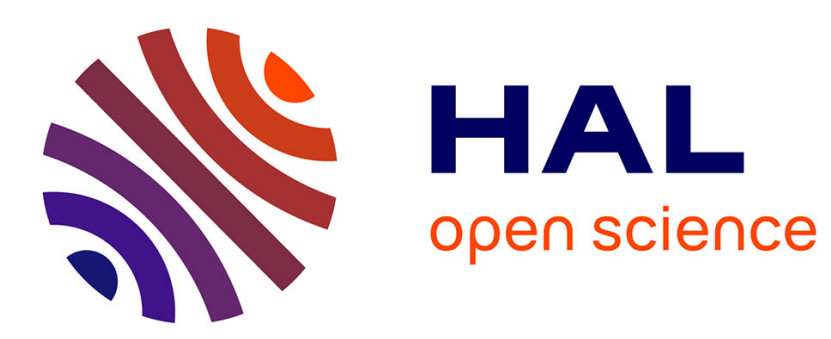

\title{
Diversity and functions of leaf-decaying fungi in human-altered streams
}

\author{
Antoine Lecerf, Eric Chauvet
}

\section{To cite this version:}

Antoine Lecerf, Eric Chauvet. Diversity and functions of leaf-decaying fungi in human-altered streams. Freshwater Biology, 2008, vol. 53 ( $\mathrm{n}^{\circ} 8$ ), pp. 1658-1672. 10.1111/j.1365-2427.2008.01986.x . hal01345995

\section{HAL Id: hal-01345995 \\ https://hal.science/hal-01345995}

Submitted on 18 Jul 2016

HAL is a multi-disciplinary open access archive for the deposit and dissemination of scientific research documents, whether they are published or not. The documents may come from teaching and research institutions in France or abroad, or from public or private research centers.
L'archive ouverte pluridisciplinaire HAL, est destinée au dépôt et à la diffusion de documents scientifiques de niveau recherche, publiés ou non, émanant des établissements d'enseignement et de recherche français ou étrangers, des laboratoires publics ou privés. 


\section{Open Archive TOULOUSE Archive Ouverte (OATAO)}

OATAO is an open access repository that collects the work of Toulouse researchers and makes it freely available over the web where possible.

This is an author-deposited version published in : http://oatao.univ-toulouse.fr/ Eprints ID : 9627

To link to this article : $10.1111 / \mathrm{j} .1365-2427.2008 .01986 . x$ URL : http://dx.doi.org/10.1111/j.1365-2427.2008.01986.x

To cite this version : Lecerf, Antoine and Chauvet, Eric Diversity and functions of leaf-decaying fungi in human-altered streams. (2008) Freshwater Biology, vol. 53 ( ${ }^{\circ}$ 8). pp. 1658-1672. ISSN 0046-5070

Any correspondence concerning this service should be sent to the repository administrator: staff-oatao@ listes-diff.inp-toulouse.fr 


\title{
Diversity and functions of leaf-decaying fungi in human-altered streams
}

\author{
ANTOINE LECERF ${ }^{1}$ AND ERIC CHAUVET \\ EcoLab - Laboratoire d'écologie fonctionnelle, UMR 5245 (CNRS-UPS-INPT), Toulouse, France
}

\begin{abstract}
SUMMARY
1. Stream conditions have been evaluated using leaf breakdown, and aquatic hyphomycetes are a diverse group of fungal decomposers which contribute to this process.

2. In field surveys of three pairs of impact-control stream sites we assessed the effect of eutrophication, mine pollution and modification of riparian vegetation on alder leaf breakdown rate in coarse and fine mesh bags and on mycelial biomass, spore production and species diversity of leaf-colonizing fungi.

3. In addition, we gathered published information on the response of leaf-colonizing fungi to these three types of perturbations. We conducted a meta-analysis of 23 published papers to look for consistent patterns across studies and to determine the relevance of four fungalbased metrics (microbial breakdown rate, maximum spore production, maximum mycelial biomass and total species richness) to detect stream impairment.

4. In our field surveys, leaf breakdown rates in coarse mesh bags were lower at impact than at paired control sites regardless of perturbation type. A similar trend was observed for leaf breakdown rates in fine mesh bags. Mycelial biomass and spore production were higher in the eutrophied stream than in the control stream. Spore production was depressed in the mine polluted stream, while it was slightly enhanced in the stream affected by forestry. Fungal diversity tended to be lower at impact than at paired control sites, though the mean and cumulative species richness values were often inconsistent. 5. Results of the meta-analysis confirmed that mine pollution reduces fungal diversity and performance. Eutrophication was not found to affect microbial breakdown rate, maximum spore production and maximum mycelial biomass in a predictable manner because both positive and negative effects were reported in the literature. However, fungal species richness was consistently reduced in eutrophied streams. Modification of riparian vegetation had at most a small stimulating effect on maximum spore production. Among the four fungal-based metrics included in the meta-analysis, maximum spore production emerged as the most sensitive indicator of human impact on streams.

6. Taken together, our findings indicate that human activities can affect the diversity and functions of aquatic hyphomycetes in streams. We also show that leaf breakdown rate and simple fungal-based metrics, such as spore production, are relevant to assess stream condition.
\end{abstract}

Keywords: aquatic hyphomycetes, eutrophication, litter decomposition, mining, riparian vegetation 


\section{Introduction}

A major challenge in freshwater ecology is to understand the consequences of human perturbations on aquatic ecosystems and to provide assessment tools and guidelines to environmental agencies and policy makers. Due to human activities, streams and rivers are among the most threatened habitats in the world (Malmqvist \& Rundle, 2002). Water chemistry has changed dramatically over the past two centuries as a result of atmospheric deposition, land use, run-off and direct disposal of waste water in the river network. Anthropogenic nutrients and toxic metals have entered and accumulated at high rates in streams. Since riparian vegetation controls in-stream biogeochemical processes and trophic flows, modification of riparian zones by agriculture, forestry and introduction of exotic species are also common sources of stream impairment (Graça et al., 2002).

It is now well established that alterations of water chemistry and riparian vegetation affect the diversity of aquatic organisms (Allan \& Flecker, 1993; Dudgeon et al., 2006), yet we still only have a partial understanding of the ecosystem-level consequences of human impacts upon streams. This is because functional indicators that directly measure the importance or rate of major ecological processes are scarce and still largely neglected, while structural indicators that describe the diversity, structure and composition of selected stream communities are unlikely to provide a reliable picture of ecosystem functions (Covich et al., 2004). Incorporating various structural and functional indicators into assessment schemes is thus essential to evaluate stream condition (Meyer, 1997).

Leaf breakdown is a key process in streams shaded by a riparian canopy and relying on plant litter as a primary energy source. A variety of human stresses have been shown to affect the rate of leaf breakdown (e.g. Niyogi, Lewis \& McKnight, 2001; Pascoal et al., 2003; Lecerf et al., 2005), which could be used to assess the functional integrity of stream ecosystems (Gessner \& Chauvet, 2002). Some investigators, however, have stressed the lack of sensitivity of this indicator (Hagen, Webster \& Benfield, 2006; Bergfur et al., 2007) and its inconsistent responses to a given perturbation type across studies or times (Lecerf et al., 2006; Bergfur, 2007). These limitations could be overcome by integrating leaf-colonizing biota into a leaf breakdown assay to make a robust multiparametric assessment tool. For example, leaf-associated invertebrates have been often used together with leaf breakdown in previous studies (e.g. Pascoal et al., 2003; Hagen et al., 2006). Likewise, it would be worth considering microbial decomposers, notably fungi, as potential ecological indicators (Solé et al., 2008).

With over 300 species described worldwide, aquatic hyphomycetes make up a diverse group of fungi primarily inhabiting well-oxygenated oligotrophic streams (Bärlocher, 1992). Aquatic hyphomycetes colonize submerged particulate organic matter, preferentially leaves from riparian vegetation which they use as a primary source of carbon. Since fungal decomposers play a pivotal role in detritus food webs, any changes in the diversity, biomass and activity of leaf-associated fungal assemblages could affect leaf breakdown rate and thus energy flow in streams (Lecerf et al., 2005; Pascoal et al., 2005b). Methods to assess diversity and performance of aquatic hyphomycetes are straightforward and can easily be applied by non-specialists (Gessner, Bärlocher \& Chauvet, 2003). Leaf breakdown in fine mesh bags is probably a good proxy of the overall performance of this group of fungi, which outperform other types of microbial decomposers (e.g. bacteria) in terms of biomass and efficiency of their enzymatic equipment (Hieber \& Gessner, 2002; Pascoal \& Cássio, 2004; Romaní et al., 2006). A common method for mycelial biomass determination is based on high performance liquid chromatography (HPLC) quantification of ergosterol, a sterol specific to fungi (Gessner et al., 2003). Aquatic hyphomycete species can be identified based on the morphology of asexual spores released in the water. After which the condition of the overall fungal assemblage can be evaluated by counting the spores released per time and leaf mass units from leaf fragments placed in incubation chambers. By combining these two approaches, the structure of the functional fungal assemblage can be assessed at different leaf decomposition stages.

Although it has been previously suggested that aquatic hyphomycetes may not be a good indicator of stream condition (Suberkropp et al., 1988), this view has not been supported by further surveys conducted in polluted streams (Krauss, Bärlocher \& Krauss, 2003; Pascoal, Cássio \& Marvanová (2005a); Solé et al., 2008). In some respects, aquatic hyphomycetes behave like many other ecological indicators, with a reduction in fungal diversity, biomass and performance associated with stress (Sridhar et al., 2001; Mesquita, Pascoal 
\& Cássio, 2007; Baudoin et al., 2008). Moreover, like primary producers that are able to use anthropogenic dissolved nutrients, the biological functions of aquatic hyphomycetes are stimulated by nutrient addition (Suberkropp, 1998; Gulis \& Suberkropp, 2003) and moderate eutrophication (Gulis, Ferreira \& Graça, 2006). Lastly, a unique feature of aquatic hyphomycetes lies in the connection between the fungal assemblage and riparian vegetation (Bärlocher \& Graça, 2002; Laitung \& Chauvet, 2005; Lecerf et al., 2005, 2007), thus making them a promising indicator for streams affected by forestry and riparian invasion by exotic plants. To date, there has been no attempt at a comprehensive evaluation of the use of aquatic hyphomycetes for assessing stream condition.

This study aimed to determine whether aquatic hyphomycetes could be used together with leaf breakdown to assess various types of human impacts on streams. We focused on three widespread perturbations: eutrophication, mine pollution and riparian forest modification. For each of these three types of perturbation, we first conducted a field survey based on a control-impact pair of stream sites located in SW-France. Previous studies, including those we conducted in the same region, have shown that all three perturbations can reduce leaf breakdown rate (Gessner \& Chauvet, 2002; Lecerf et al., 2005, 2006), while the effects on aquatic hyphomycetes may be more variable. Because conducting field surveys at a small number of sites would have limited our ability to generalize the results, we also analysed published data on the response of aquatic hyphomycetes to the same three types of perturbations. Combining field surveys and meta-analysis allowed us to search for general response patterns for common descriptors of fungal assemblages and performance, and to compare their relevance in assessing stream condition.

\section{Methods}

\section{Field surveys}

Study sites. Experiments were conducted in six low (second-fourth) order streams situated within a $150 \mathrm{~km}$ radius around of the city of Toulouse (SW France). Riparian zones were colonized by dense vegetation dominated by trees and shrubs. The streams were divided into three control-impact pairs for the three types of impairment; each pair consisted of one heavily perturbed site and one nearby relatively unperturbed site. Stream pairs were based on having similar characteristics (geology, streambed morphology and stream size) other than those mediated by the perturbation. Because water characteristics were key criteria for site selection, all streams were analysed for relevant water parameters determined at several occasions during the field surveys ( $n=3-6$; see Table 1 ). Temperature was recorded every $2 \mathrm{~h}$ (SmartButton; ACR System Inc., Surrey, Canada). pH, conductivity and dissolved oxygen were determined in the field using WTW portable equipment (WTW GmbH, Weilheim, Germany). Suspended matter was assessed by filtration of 1-2 L of stream water on pre-weighted GF/C filter (Whatman International Ltd., Maidstone, U.K.). Alkalinity, $\mathrm{NO}_{3}, \mathrm{PO}_{4}, \mathrm{NH}_{4}$ and $\mathrm{NO}_{2}$ were determined following standard methods (APHA, 1998). Heavy metals in water of the streams used to assess the effects of mining were quantified using ICP atomic emission spectrometer. Woody plant species richness in the riparian zone of the site affected by forestry and its control was assessed by sampling leaf packs in streams in early and late autumn (Lecerf et al., 2007).

The eutrophied stream (Ei) received the effluent of a rudimentary wastewater treatment plant (purification capacity of 150 population equivalent) from a small city near Montauban. Although the control site (Ec) had elevated nitrate concentration, probably due to agricultural runoff and contaminated groundwater, concentration of phosphate and ammonium was about 16-fold higher at Ei (Table 1). The stream affected by mining (Mi) received arsenic-rich effluent and runoff of the gold mine of Salsigne located near the city of Carcassonne. The mine effluent was warmer than the stream, elevating the temperature at Mi. Due to the geology of this region, nonnegligible concentrations of arsenic were observed at the control site $(\mathrm{Mc})$, yet there was still five-fold higher arsenic concentration at Mi (Table 1). The site impacted by forestry (Fi) was situated far (c. $9 \mathrm{~km}$ ) upstream of Mc. The occurrence of diverse riparian vegetation and the presence of a reservoir in between $\mathrm{Fi}$ and Mc ensured that riparian forest modification at Fi did not affect the downstream site (Mc). Selective logging of trees other than beech (Fagus silvatica L.) during forest regeneration created an almost pure beech stand along the stream from c. 200-m downstream of Fi to the source. The control stream $(\mathrm{Fc})$ was 
Table 1 Description of the control-impact pairs of stream sites

\begin{tabular}{|c|c|c|c|c|c|c|}
\hline \multirow[b]{2}{*}{ Variable } & \multicolumn{2}{|c|}{ Eutrophication } & \multicolumn{2}{|c|}{ Mine pollution } & \multicolumn{2}{|l|}{ Forestry } \\
\hline & $\begin{array}{l}\text { Control } \\
\text { Tescou Ec }\end{array}$ & $\begin{array}{l}\text { Impact } \\
\text { Tauge Ei }\end{array}$ & $\begin{array}{l}\text { Control } \\
\text { Linon Mc }\end{array}$ & $\begin{array}{l}\text { Impact } \\
\text { Gresillou Mi }\end{array}$ & $\begin{array}{l}\text { Control } \\
\text { Fraissegne Fc }\end{array}$ & $\begin{array}{l}\text { Impact } \\
\text { Linon } \mathrm{Fi}\end{array}$ \\
\hline \multicolumn{7}{|l|}{ Catchment attributes } \\
\hline Latitude N & $43^{\circ} 54^{\prime} 41^{\prime \prime}$ & $44^{\circ} 03^{\prime} 07^{\prime \prime}$ & $43^{\circ} 20^{\prime} 30^{\prime \prime}$ & $43^{\circ} 20^{\prime} 02^{\prime \prime}$ & $43^{\circ} 24^{\prime} 44^{\prime \prime}$ & $43^{\circ} 24^{\prime} 48^{\prime \prime}$ \\
\hline Longitude E & $1^{\circ} 45^{\prime} 45^{\prime \prime}$ & $1^{\circ} 26^{\prime} 43^{\prime \prime}$ & $2^{\circ} 13^{\prime} 54^{\prime \prime}$ & $2^{\circ} 22^{\prime} 36^{\prime \prime}$ & $2^{\circ} 14^{\prime} 01^{\prime \prime}$ & $2^{\circ} 15^{\prime} 23^{\prime \prime}$ \\
\hline Altitude (m.a.s.1.) & 180 & 98 & 369 & 210 & 800 & 710 \\
\hline Slope $\left(\mathrm{m} \mathrm{m}^{-1}\right)$ & 0.004 & 0.004 & 0.020 & 0.025 & 0.050 & 0.050 \\
\hline Catchment area $\left(\mathrm{km}^{2}\right)$ & 45.3 & 25.9 & 13.3 & 12.6 & 1.4 & 0.7 \\
\hline Distance from spring $(\mathrm{km})$ & 8.8 & 13.4 & 10.0 & 4.6 & 1.1 & 1.2 \\
\hline \multicolumn{7}{|l|}{ Water characteristics (mean value) } \\
\hline Temperature $\left({ }^{\circ} \mathrm{C}\right)$ & 6.5 & 7.4 & 8.3 & 11.8 & 7.0 & 8.1 \\
\hline $\mathrm{pH}$ & 8.2 & 8.0 & 8.2 & 8.3 & 6.5 & 6.7 \\
\hline $\mathrm{O}_{2}\left(\mathrm{mg} \mathrm{L}^{-1}\right)$ & 14 & 13.8 & 18.1 & 14.2 & - & - \\
\hline Suspended matter $\left(\mathrm{mg} \mathrm{L}^{-1}\right)$ & 10.8 & 14.2 & 11.0 & 39.3 & 4.8 & 3.2 \\
\hline Conductivity $\left(\mu \mathrm{S} \mathrm{cm}{ }^{-1}\right)$ & 564 & 648 & 170 & 575 & 41 & 75 \\
\hline Alkalinity $\left(\mathrm{mg} \mathrm{CaCO}_{3} \mathrm{~L}^{-1}\right)$ & 266.3 & 296.4 & 38 & 65 & 7.3 & 28.8 \\
\hline $\mathrm{NO}_{3}\left(\mu \mathrm{g} \mathrm{N} \mathrm{L}^{-1}\right)$ & 3256 & 3545 & 2542 & 1476 & 1160 & 395 \\
\hline $\mathrm{PO}_{4}\left(\mu \mathrm{g} \mathrm{N} \mathrm{L}^{-1}\right)$ & 6.3 & 100.7 & 23.5 & 20.7 & 3.1 & 4.0 \\
\hline $\mathrm{NH}_{4}\left(\mu \mathrm{g} \mathrm{N} \mathrm{L}^{-1}\right)$ & 22.4 & 387.6 & 98.7 & 65.5 & 16.9 & 10.6 \\
\hline $\mathrm{NO}_{2}\left(\mu \mathrm{g} \mathrm{N} \mathrm{L}^{-1}\right)$ & 10.4 & 34.2 & - & - & 0.9 & 0.3 \\
\hline Arsenic $\left(\mu \mathrm{g} \mathrm{L}^{-1}\right)$ & - & - & 24 & 122 & - & - \\
\hline Manganese $\left(\mu \mathrm{g} \mathrm{L}^{-1}\right)$ & - & - & 25 & 45 & - & - \\
\hline Woody plant species richness & $>10$ & $>10$ & $>10$ & $>10$ & 12 & 4 \\
\hline
\end{tabular}

- , undetermined parameters.

lined by a mixed deciduous forest that had three-fold more woody plant species than Fi. Since these streams were situated in contiguous catchments, the higher alkalinity and lower nitrate concentration at Fi was thought to be partly mediated by the difference in riparian forest type (Table 1 ).

Construction and processing of leaf bags. Following the method proposed by Gessner \& Chauvet (2002), we determined leaf breakdown rate in coarse and fine mesh bags. Unlike the coarse mesh bags used to estimate total breakdown rate, the fine mesh bags did not allow leaf-consuming macroinvertebrates to access the leaves exposed in the study streams. We used senescent leaves of alder [Alnus glutinosa (L.) Gaertn.] collected near Ec, just after abscission in autumn 2002. Five grams $( \pm 0.05$, with exact mass recorded) of air-dried leaves were placed into $10-\mathrm{mm}$ plastic mesh bags and 0.5-mm nylon mesh bags directly after the leaves had been wetted using a spray bottle to prevent breakage during handling. Twelve fine mesh bags and 12 coarse mesh bags were introduced at the E and F sites in December 2002 and at the M sites in November 2003. The leaf bags were secured in streams by nylon lines anchored to iron bars driven into streambed sediments. Four leaf bags were collected from the E sites after 7, 14 and 38 days, from the $\mathrm{M}$ sites after 7, 14, 32 days and from the F sites after 7, 34, 69 days. Leaf bags were stored individually in plastic zip-lock bags at stream temperature during transport to the laboratory. High snowfall in the Montagne Noire prevented earlier access the F sites for the second and third dates of leaf bag collection.

Leaves were washed individually to remove sediments, exogenous organic matter and macroinvertebrates. Fungal analyses were conducted on leaves exposed in coarse mesh bags at E and F sites, and in fine mesh bags at the $\mathrm{M}$ sites where rapid breakdown in coarse mesh bags would have limited the availability of leaf samples to the first sampling date. Two sets of five 12-mm diameter discs were cut from five leaves, avoiding the central veins; one set was frozen at $-18{ }^{\circ} \mathrm{C}$ until processing for ergosterol extraction, and the other was conserved fresh to induce fungal spore production. The remaining leaf litter was dried at $105{ }^{\circ} \mathrm{C}$ for $48 \mathrm{~h}$ and weighed to the nearest $0.01 \mathrm{~g}$ and ground. Portions of leaf material of about $500 \mathrm{mg}$ were ashed at $550{ }^{\circ} \mathrm{C}$ for $4 \mathrm{~h}$ and weighed to 
determine the organic matter content. The leaf mass remaining in the bags was expressed as a ratio between final and initial leaf ash-free dry mass (AFDM), with the latter being determined from four extra leaf-bags constructed in autumn 2002 and 2003 but kept in the laboratory.

The five fresh leaf discs were placed into $100-\mathrm{mL}$ Erlenmeyer flasks filled with $25 \mathrm{~mL}$ of filtered (Whatman GF/F) stream water. Production of fungal asexual spores was stimulated by gentle shaking using an orbital path at $10{ }^{\circ} \mathrm{C}$ for $48 \mathrm{~h}$ (Gessner et al., 2003). Thereafter, spore suspensions were transferred into 50-mL polyethylene centrifuge tubes, and the volume was adjusted to $35 \mathrm{~mL}$ with $2 \mathrm{~mL}$ of $37 \%$ formalin and distilled water. The discs were then oven-dried and weighed to the nearest $0.1 \mathrm{mg}$. Spore suspensions were supplied by $1 \mathrm{~mL}$ of $0.01 \%(\mathrm{w} / \mathrm{v})$ Triton X-100 (Prolabo, Paris, France) and stirred gently for at least $10 \mathrm{~min}$ to ensure uniform distribution of spores. Five millilitre aliquots were filtered through a membrane filter (Whatman, $5 \mu \mathrm{m}$ pore size), and the spores on the filter were stained with $0.1 \%$ Trypan blue in $60 \%$ lactic acid. Two hundred spores per sample were counted and identified to species-level under the microscope $(\times 320)$. Spore production was calculated as the number of spores released per milligram leaf AFDM per day.

The frozen leaf discs were used to determine ergosterol content as a measure of fungal biomass (Gessner et al., 2003). The extraction and quantification method is based on solid-phase extraction (cartridges Waters Oasis HLB, 60 mg, 3 cc) and HPLC (see Lecerf et al., 2005). Fungal biomass in leaves was expressed as ergosterol mass per milligram leaf AFDM.

Statistical analyses. We calculated temperature-corrected breakdown rates to account for difference in water temperature between control and impact sites. For each pair of sites, we assessed differences in leaf breakdown rates between control and impact sites, and between coarse and fine mesh bags using separate generalized linear models based on a normal distribution (Lindsey, 1997). The identity link-function was used to compare breakdown rates under the assumption of a linear relationship between leaf AFDM remaining and degree-days, while the log-link function assumed exponential relationship. The model with the highest loglikelihood (L) was chosen to compare the breakdown coefficients and intercepts.
Like for ANCOVA, a significant interaction between the categorical factor (site or/and mesh bag size) and the covariate (degree-days) indicated differences in leaf breakdown rates. Significance was assessed using the likelihood ratio test based on the chi-square statistic $\left(\chi^{2}\right.$, d.f. $\left.=1\right)$. Linear and exponential breakdown rates were determined by linear and nonlinear regression, respectively. To be consistent with the literature, we presented only the exponential breakdown rates (Table 2).

For each pair of sites, we assessed differences in spore production, fungal biomass and species richness between control and impact sites and between sampling dates using separate factorial ANOVAs. When necessary, data were square-root or log-transformed to comply with the conditions of normality and equality of variance. All tests were done using STATISTICA 6 software (StatSoft Inc., Tulsa, OK, U.S.A.).

Differences in fungal assemblages between control and impact sites were assessed through species richness, Pielou evenness index, the probability of inter-specific encounter (PIE), and Jaccard and BrayCurtis similarity indices (Krebs, 1999). All these indices were calculated from cumulative frequencies of occurrence of aquatic hyphomycetes species on the three sampling dates.

\section{Meta-analysis}

Database construction. We searched for literature data on the effect of eutrophication, mine pollution and riparian vegetation modification on leaf-associated fungi in streams. We deliberately did not consider the experimental studies, either laboratory or in situ, which were unlikely to reproduce the cumulative ecosystem effects of the complex perturbations observed in the real world. To be selected, studies must have included at least one control and one impact site, for which at least one of the following fungal parameters could be extracted from the paper: microbial breakdown rate of leaves (in fine mesh bags $\leq 1 \mathrm{~mm}$ ), maximum fungal spore production rate, maximum fungal biomass as determined by ergosterol concentration and total fungal species richness. These data were recorded for each leaf species and/or time period used to survey the sites. We discarded studies based only on one sampling date because of the uncertainty in the determination 
of the fungal parameters. When possible, we used data on fungal colonization of leaves exposed in the most realistic condition (i.e. coarse mesh bags). When more than two sites were used, we selected one site at each end of the gradient unless there was a pair of sites that represented a better compromise between the magnitude of difference caused by the perturbation and the similarity in terms of other stream characteristics.

Effect size and statistical inferences. The effect size of perturbations was quantified as the natural logarithm of the response ratio impact : control of each of the four fungal parameters (Hedges, Gurevitch \& Curtis, 1999). In meta-analysis, observations (individual lines) are typically weighted by a measure of precision of the effect size. In our study, we used weights to deal with another issue in our data set, namely multiple (dependent) observations from the same stream pairs. This problem generally arose from the combination of several leaf species and/or survey periods to assess streams in single studies or from studies published separately but conducted in the same streams. Since the appropriate level of replication was the stream pair, the weight for a stream pair $(=1)$ was divided evenly among non-independent observations. For example, a study that explicitly included results from geographically-distant streams counted more heavily (sum of weight $=n$ stream pairs) than a single study including repeated observations on a single stream pair (sum of weight $=1$ ).

We determined bootstrapped $95 \%$ confidence limits corrected for small samples to test for significant effect (Adams, Gurevitch \& Rosenberg, 1997). Difference among perturbation types was assessed using MonteCarlo randomization test for each of the four fungal parameters. We used METAWIN for the computation of bootstrapped confidence limits and randomization test (Rosenberg, Adams \& Gurevitch, 2000).

\section{Results}

Field surveys

General trends. Temperature-corrected breakdown rates were accurately estimated by the exponential model with an unconstrained intercept (Table 2). The linear model was equally relevant $\left(r^{2}=0.558-0.982\right)$ and exponential and linear breakdown rates were closely related $\left(k_{\mathrm{c}}, r=0.955, P=0.0030 ; \mathrm{k}_{\mathrm{f}}, r=0.986\right.$, $P<0.0001$ ), suggesting that they were interchangeable. Breakdown coefficients in Table 2 were determined using nonlinear regression models which had higher coefficients of determination $\left(r^{2}\right)$ than linearized regression models for four out of six $k_{\mathrm{c}}$-values (Table S1). Moreover, even when models have comparable goodness-of-fit, the two approaches could produce very different estimates of $k_{\mathrm{c}}$ and even lead to opposite conclusions (Table S1: Fc versus Fi). In contrast, microbial breakdown rate was not greatly affected by the estimation technique.

Total leaf breakdown rate as determined in coarse mesh bags was always higher than microbial breakdown rate as determined in fine mesh bags (the three generalized linear models gave $\chi^{2}>46.6$, $P<0.00001)$. A common trend in our data set was slower leaf breakdown at impact compared to control sites regardless of the perturbation type (Table 1). Moreover, the magnitude of difference varied among stream pairs and in one case depended on the bag mesh size (see Eutrophication).

All fungal parameters varied with time, with the pattern of temporal variation of a given parameter being generally consistent across sites (Fig. 1). Fungal
Table 2 Breakdown coefficients (SE) of alder leaves calculated for each site

\begin{tabular}{lllllll}
\hline Site & $k_{\mathrm{c}}\left(\right.$ degree-days $\left.^{-1}\right)$ & Intercept & $r^{2}$ & $k_{\mathrm{f}}\left(\right.$ degree-days $\left.^{-1}\right)$ & Intercept & $r^{2}$ \\
\hline Ec & $0.0083(0.0014)$ & 1.09 & 0.873 & $0.0010(0.00008)$ & 0.83 & 0.945 \\
$\mathrm{Ei}$ & $0.0014(0.0004)$ & 0.83 & 0.561 & $0.0008(0.00013)$ & 0.79 & 0.800 \\
$\mathrm{Mc}$ & $0.0099(0.0015)$ & 1.40 & 0.928 & $0.0031(0.00030)$ & 0.92 & 0.920 \\
$\mathrm{Mi}$ & $0.0057(0.0012)$ & 1.36 & 0.847 & $0.0017(0.00012)$ & 0.92 & 0.958 \\
$\mathrm{Fc}$ & $0.0067(0.0007)$ & 1.15 & 0.950 & $0.0013(0.00021)$ & 0.89 & 0.780 \\
$\mathrm{Fi}$ & $0.0060(0.0006)$ & 1.11 & 0.950 & $0.0009(0.00015)$ & 0.78 & 0.770 \\
\hline
\end{tabular}

$k_{\mathrm{c}}$ and $k_{\mathrm{f}}$ are exponential breakdown rates of leaves enclosed in coarse and fine mesh bags respectively. The model intercept and coefficient of determination are also given. Site abbreviations are given in Table 1. 


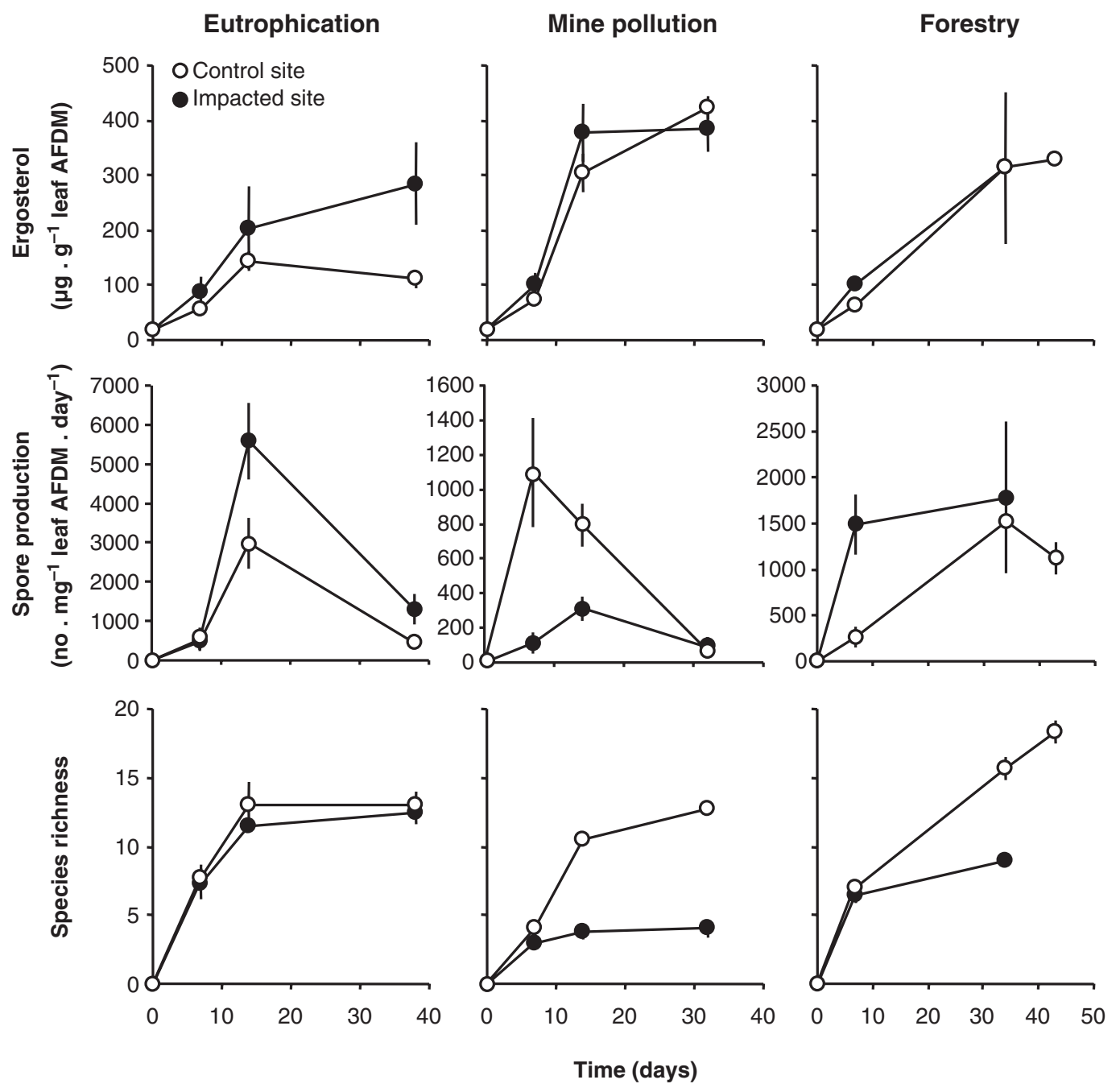

Fig.1 Mycelial biomass, spore production and species richness of aquatic hyphomycetes on alder leaves decomposing at sites impacted by eutrophication, mine pollution and forestry and their paired control sites. Fungal data for eutrophication and forestry were determined from leaves exposed in coarse mesh bags and data for mine pollution were determined from leaves exposed in fine mesh bags. Note the different scale on the vertical axis for spore production.

biomass in leaves increased exponentially during approximately the first 2 weeks of leaf exposure before reaching a plateau (Fig. 1). Spore production was better described by a hump-shape function of time and the peaks were not always synchronized (see Mine pollution and Forestry). Fungal species richness increased with time in all streams (Fig. 1). A total of 36 aquatic hyphomycete taxa were identified in this study (see Table S2).

Eutrophication. Total breakdown rate was sixfold higher at the control site (Table 2). A generalized linear model assuming exponential breakdown rates
( $L=64.5$ ), performed better than a model assuming linear breakdown rates $(L=61.6)$. Thus, breakdown coefficients were compared between sites and bag mesh size using the former model. Although the main effect of site was significant $\left(\chi^{2}=39.7, P<0.00001\right)$, total but not microbial breakdown rate was lower at the impact site as indicated by the interaction between site and bag mesh size $\left(\chi^{2}=35.6, P<0.00001\right)$ and the $95 \%$ confidence interval limits as a post hoc test. Intercepts of the model differed between sites $\left(\chi^{2}=6.7, P=0.0096\right)$ and bag mesh sizes $\left(\chi^{2}=6.4\right.$, $P=0.0114)$. The highest intercept values were observed for the control site and coarse mesh bags. 
Leaves incubated in the eutrophied stream had nearly twofold greater fungal biomass (ANOVA, $F=18.8, P=0.0007)$ and spore production $(F=4.8$, $P=0.0441)$. These differences did not depend on time (site-by-time interaction, $P>0.14$ ). Mean species richness did not differ between sites at any time (site, $F=0.8, \quad P=0.369 ;$ site-by-time interaction, $F=0.10, \quad P=0.901$; Fig. 1), although three more fungal species (Tetrachaetum elegans Ingold, Clavatospora longibrachiata (Ingold) Marvanová \& S. Nilsson and Heliscella stellata (Ingold \& Cox) Marvanová) were recorded at the control site. According to Pielou evenness and PIE dominance indices, the fungal assemblage at the impact site had a higher evenness than at the control site (Table 3). Similarity indices were high, suggesting that fungal assemblage did not fundamentally differ between sites. However, Flagellospora curvula Ingold dominant at the control site was $40 \%$ less abundant at the impact site. Lemmoniera aquatica de Wilderman was twofold less abundant at the impact site, while ?Anguillospora mediocris Gönczöl \& Marvanová and Tetracladium marchalianum de Wilderman were twofold more frequent at the eutrophied than at the control site (see Table S2).

Mine pollution. Leaf breakdown rates were nearly twofold higher at the control site than at the site impacted by the mine effluent (Table 2). The generalized linear model assuming linearity $(L=82.8)$ performed much better than a model assuming exponential breakdown rates $(L=52.8)$. The difference between sites was significant $\left(\chi^{2}=32.1\right.$, $P<0.00001)$ and independent of the bag mesh size (site-by-bag mesh size interaction, $\chi^{2}=2.2, P=0.134$ ). Intercepts differed between bag mesh sizes $\left(\chi^{2}=22.7\right.$,
$P<0.00001)$, but not between sites $\left(\chi^{2}=3.3\right.$, $P=0.0678)$.

Fungal biomass was similar at control and impact sites $(F=0.69, \quad P=0.418 ;$ site-by-time interaction, $F=1.5, P=0.239$ ). There was a threefold difference in the peak spore production between sites (Fig. 1). Spore production $(F=20.5, P=0.0003)$ and species richness $(F=198, P<0.00001)$ were both lower in the mine-polluted stream (Fig. 1). In addition, the significant interaction with time indicated a difference in colonization dynamics (with spore production, $\quad F=7.1, \quad P=0.0053$; with species richness, $F=35.3, P<0.00001)$. Peak spore production occurred later at the impact site. Species richness reached a plateau at 7 days at the impact site, while it increased until the last sampling date at the control site (Fig. 1). There were 13 more species at the control site than at the impact site, and evenness was also reduced by mine pollution (Table 3). The low similarity indices indicated that fungal assemblage was dramatically altered. The dominant species clearly differed between the control site (F. curvula) and the impact site (Lunulospora curvula Ingold).

Forestry. We used a linear $(L=72.6)$ rather than an exponential model $(L=68.3)$ to compare leaf breakdown rates. Leaf breakdown was slightly $(<2$-fold), but significantly, higher at the control site $\left(\chi^{2}=7.9\right.$, $P=0.0048$ ), irrespective of the bag mesh size (interaction: $\left.\chi^{2}<0.1, P=0.983\right)$. This difference between sites was probably due to long-term leaf breakdown, since models for the impact site had slightly lower intercepts $\left(\chi^{2}=4.9, P=0.02629\right)$ than models for the control site, suggesting that initial mass loss in coarse and fine mesh bags (no significant interaction with
Table 3 Diversity and similarity indices for aquatic hyphomycete assemblages on alder leaves exposed in streams impacted (I) by three different perturbations and at paired control sites (C)

\begin{tabular}{|c|c|c|c|c|c|c|c|c|}
\hline \multirow[b]{2}{*}{ Perturbation } & \multicolumn{2}{|c|}{$\begin{array}{l}\text { Species } \\
\text { richness }\end{array}$} & \multicolumn{2}{|c|}{ Evenness } & \multicolumn{2}{|l|}{ PIE } & \multicolumn{2}{|c|}{$\%$ Similarity $\mathrm{C}$ versus $\mathrm{I}$} \\
\hline & $\mathrm{C}$ & I & $\mathrm{C}$ & I & $\mathrm{C}$ & I & Jaccard & Bray-Curtis \\
\hline Eutrophication & 20 & 17 & 0.520 & 0.610 & 0.338 & 0.244 & 85.7 & 73.6 \\
\hline Mining & 21 & 8 & 0.273 & 0.165 & 0.695 & 0.871 & 31.8 & 3.3 \\
\hline Forestry & 26 & 26 & 0.699 & 0.646 & 0.140 & 0.178 & 100.0 & 77.7 \\
\hline
\end{tabular}

Fungal data for eutrophication and forestry were determined from leaves exposed in coarse mesh bags and data for mine pollution were determined from leaves exposed in fine mesh bags.

PIE, probability of inter-specific encounter. 
bag mesh size: $\left.\chi^{2}=1.3, P=0.259\right)$ tended to be faster at the impact site.

Fungal data were not available for the impact site on the last sampling date because there was not enough leaf material remaining to cut whole leaf discs. Therefore, we did not assess the time-by-site interaction in ANOVA. Mycelial biomass did not differ between sites $(F=0.5, P=0.505)$. Spore production was almost significantly higher in the stream impacted by forestry ( $F=4.5, P=0.0513$; Fig. 1$)$, but the peak in spore production did not clearly differ between sites (Fig. 1). Mean fungal richness was higher at the control site $(F=10.5, P=0.0059)$. However, the same number of fungal species were recorded in the two streams overall, even though data were missing for the impact stream. Evenness and PIE were similar at both sites (Table 3). All the species recorded were common to the two sites, resulting in a $100 \%$ similarity according to Jaccard index. There were only small differences in relative abundance of some species as suggested by the Bray-Curtis similarity index. Notably, T. elegans was threefold more frequent at the control site, while C. longibrachiata was about twofold more frequent at the impact site.

\section{Meta-analysis}

In addition to the field surveys, our data set consists of results from 23 published papers (see Appendix S1). This translated into a total of 13, 11 and 18 observations (dependent and independent) on stream eutrophication, mine pollution and riparian vegetation alterations respectively. Due to pseudo-replicates and missing values, mean effect size and bootstrap confidence limits were determined based on three to six different pairs of sites (Fig. 2). Most of the studies were conducted in temperate regions in Europe and North America, and only two studies were conducted in different climates in subtropical (Hong Kong) and dry (Nevada desert) regions.

At least one out of the four fungal parameters responded to a given type of perturbation in a predictable manner (where 95\% confidence interval for the log response ratio does not overlap 0; Fig. 2). The log response ratio of all fungal metrics depended on the perturbation type (randomization test: $P<0.05)$. Eutrophication consistently reduced fungal richness, whereas mean effect size varied around 0 for

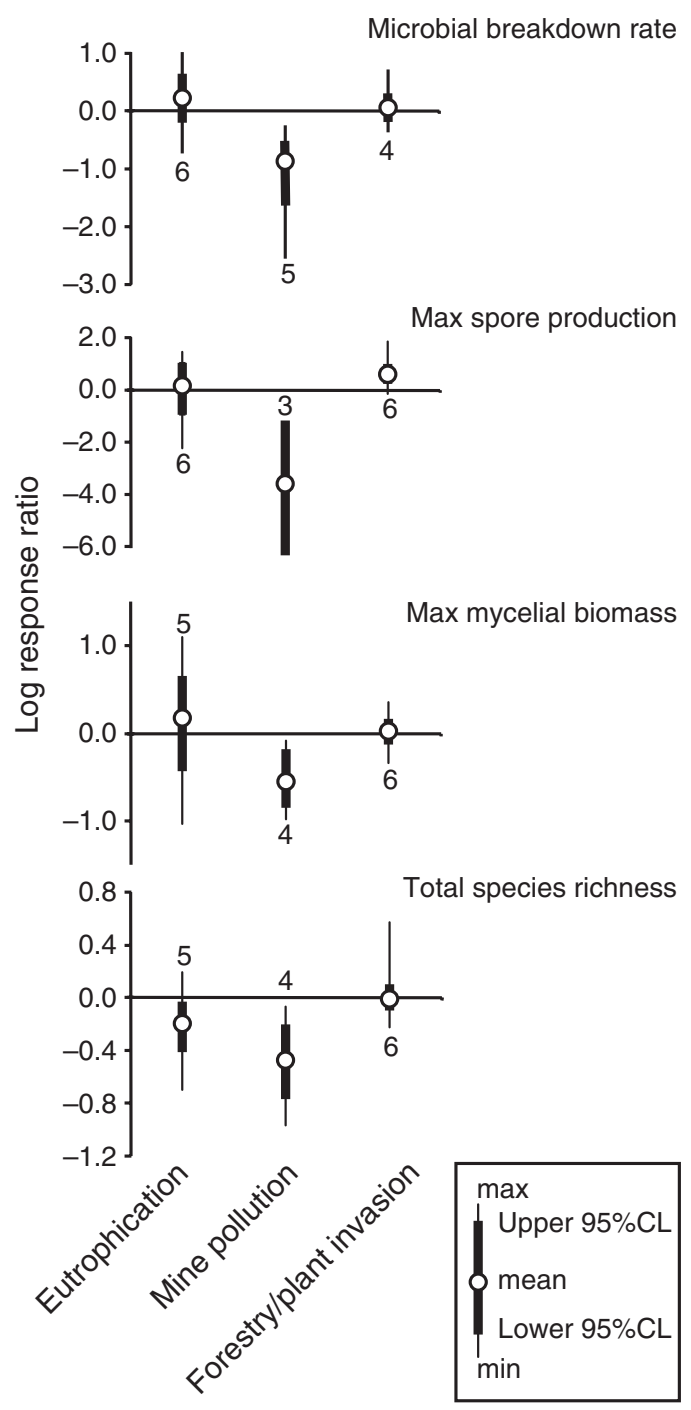

Fig. 2 Meta-analysis of the log response ratio of four fungalbased metrics to quantify the effect of eutrophication, mine pollution and modification of riparian vegetation. The number of stream pairs (=sum of weights) used for the determination of the mean effect size and $95 \%$ bootstrap confidence limits (CL) is indicated.

the other fungal parameters (Fig. 2). Mine pollution was reported to consistently reduce microbial breakdown rate, maximum spore production, maximum fungal biomass and fungal diversity in all studies (Fig. 2). Maximum spore production had by far the largest mean effect size (-3.6). Modification of riparian vegetation, whether mediated by forestry or biological invasion by exotic species, had a slight but significant positive effect on maximum spore production (Fig. 2). Although log response ratio of species richness showed a larger range of variation of effect 
size of riparian vegetation modification, aquatic hyphomycetes displayed overall weaker response to this perturbation type than to eutrophication or mine pollution (Fig. 2).

There was a strong relationship between the log response ratio of maximum spore production and the $\log$ response ratio of microbial breakdown rate ( $r=0.952, P=0.0003$; Fig. 3 ). The log response ratio of maximum fungal biomass was positively but less strongly correlated to the log response ratios of maximum spore production $(r=0.689, P=0.0067)$ and of microbial breakdown rate $(r=0.655$, $P=0.0397)$. Correlations involving the log response ratio of species richness were all positive but nonsignificant $(r<0.490, P>0.0692)$.

\section{Discussion}

Two important messages emerge from our study. First, the results of our field surveys support the notion that total leaf breakdown rate is a reliable indicator of the functional integrity of streams affected by various anthropogenic stresses. Secondly, while previous investigators have stressed the advantage of assessing leaf-associated invertebrates, this paper makes a case for integrating aquatic hyphomycetes into leaf bag experiments. Our field surveys have illustrated the applicability and relevance of standard methods to assess fungal diversity and performance in human-altered streams. Moreover, meta-analysis revealed that the direction and magnitude of the

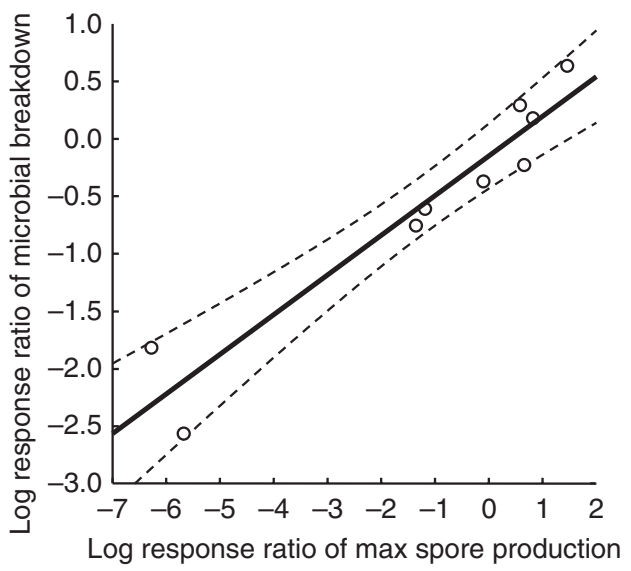

Fig. 3 Relationship between the log response ratio of microbial breakdown rate and the log response ratio of spore production. The solid line represents a weighted linear regression and dash lines represent 95\% confidence limits. change in the fungal-based indicators varies with the type of perturbation. Lastly, we have shown that spore production is a sensitive indicator of the effects of anthropogenic stresses on the performance of aquatic hyphomycetes and more generally of litter dynamics in streams.

\section{Fungal responses to different perturbations}

Mine pollution can have a strong negative effect on the reproductive ability, biomass accumulation and diversity of aquatic hyphomycetes (Fig. 2). Although mine pollution is often associated with changes in dissolved minerals and $\mathrm{pH}$, which may also affect aquatic fungi (Thompson \& Bärlocher, 1989), the reduction of fungal performance and species diversity in polluted streams was more probably caused by the toxic effect of heavy metals. This has been clearly demonstrated in laboratory experiments assessing the effect of various types of metallic ions $(\mathrm{Cd}, \mathrm{Al}, \mathrm{Zn}, \mathrm{Cu})$ on individual fungal isolates and realistic assemblages (Abel \& Bärlocher, 1984; Chamier \& Tipping, 1997; Duarte et al., 2008). Moreover, differences in tolerance among fungal species have been described as a general determinant of the structure of aquatic hyphomycete assemblages in mine polluted streams (Bermingham, Maltby \& Cooke, 1996; Guimarães-Soares et al., 2006). In our field survey, the dominance of L. curvula in a stream polluted by gold mine effluent may indicate that this species is tolerant to arsenic, which is indeed an extremely toxic metal likely to reduce leaf breakdown rate and microbial decomposer activity in streams (Chaffin et al., 2005). However, the apparent replacement of F. curvula by L. curvula in the polluted streams (see Table S2) could also be accounted for by the elevated stream temperature, since the latter species is well known for its strong affinity to warm waters (Chauvet \& Suberkropp, 1998).

Results from our field surveys and meta-analysis indicated that eutrophication, as caused by domestic effluents and agricultural run-off, can have variable effects on aquatic hyphomycetes, resulting in increased or decreased fungal-based metrics. The consistent erosion of fungal diversity in eutrophied streams reported here contrasts with the inconclusive results of in situ nutrient enrichment experiments showing either a positive effect (Gulis \& Suberkropp, 2003) or no effect at all (Ferreira, Gulis \& Graça, 2006b). A large amount of experimental data indicated 
that anthropogenic nutrients can stimulate fungal spore production and mycelial biomass on leaves (Suberkropp, 1998; Grattan \& Suberkropp, 2001; Gulis \& Suberkropp, 2003). To our knowledge, the negative effect of nutrients alone on aquatic hyphomycetes has never been reported. Together with our findings, this therefore strongly suggests that factors other than nutrient enrichment are responsible for the loss of fungal diversity and functions in heavily eutrophied streams (Raviraja, Sridhar \& Bärlocher, 1998). Specifically, there are indirect observations indicating that oxygen depletion on the surface of leaves, caused by intense deposition of fine sediments and oxidation of organic matter by other microorganisms, is detrimental to aquatic hyphomycetes (Raviraja et al., 1998; Pascoal et al., 2005b; Mesquita et al., 2007). In such adverse conditions, aquatic hyphomycetes may be outcompeted by other microorganisms that proliferate in extreme eutrophic environments (e.g. bacteria: Mille-Lindblom, Fischer \& Tranvik, 2006). Another explanation to the deleterious effects of eutrophication on fungi lies in the regular occurrence of toxic organic and inorganic micropollutants in sewage effluents or agricultural, industrial and urban run-offs (Cheng, Andre \& Chiang, 1997).

Modifications of riparian vegetation caused by forestry or invasion by exotic species were found to have a slight and rather unpredictable effect on aquatic hyphomycetes. Previous studies on fungal assemblages in streams have proposed that species composition and diversity of riparian vegetation and stream fungal community are intricately related (Bärlocher \& Graça, 2002; Laitung \& Chauvet, 2005). Specifically, the conversion of diverse forest into pure beech stands has been found to reduce fungal species richness on slow decomposing leaves in streams of the Montagne Noire (Lecerf et al., 2005). In our field survey, which was based on a subset of those streams, the total number of fungal species was not affected by forest type, even though mean values by sampling date were indeed higher in the control than in the impact stream. This inconsistency, together with the results of our meta-analysis, indicates that spore production is a more reliable metric than fungal diversity to assess the stream consequences of altered riparian vegetation. Whether aquatic hyphomycetes respond to changes in riparian vegetation (and litter input) or to indirect consequences of altered stream physical or chemical characteristics still remains unclear. Some stream reaches affected by plantation or invasion by exotic species had also higher alkalinity (this study) or nutrient concentrations (Pozo et al., 1998; Lecerf et al., 2007). This may be caused by the control of riparian vegetation on biogeochemical stream processes and/or the co-occurrence of additional perturbations. However, it is also possible that aquatic hyphomycetes respond to the enhancement of leaf standing stock in impact streams due to the accumulation of slow decomposing leaf litter from the dominant plant species in altered riparian vegetation (Laitung et al., 2002; Lecerf et al., 2007).

Other factors than perturbation type (defined as three categories) could account for the variation in fungal metrics (Fig. 2). Unfortunately, the paucity of data available for our meta-analysis did not allow us to assess these additional sources of variation. However, it is expected that intrinsic features of perturbation (e.g. types and combination of pollutants, intensity), environmental context (study region, stream abiotic characteristics) and experimental design influence the direction and magnitude of changes in fungal diversity and performance. Concentrations of nutrients or heavy metals in water (e.g. Niyogi et al., 2001; Gulis et al., 2006) and severity/type of modification in riparian vegetation (Graça et al., 2002; Lecerf et al., 2007) may be the most important of these factors. In contrast, differences in the leaf species used (e.g. Gulis et al., 2006) and in bag mesh size (Ferreira \& Graça, 2006a) are thought to be comparatively minor sources of variation in the data set.

\section{A search for fungal-based indicators}

Spore production is an excellent candidate metric to assess aquatic hyphomycete functions. We found that spore production varied widely between control and impact sites and was the most sensitive of the fungal parameters studied here. Furthermore, positive covariations between the log response ratio of maximum spore production, microbial breakdown and maximum fungal biomass suggest that a single value of spore production (peak) condenses a large amount of information of the condition of the fungal assemblage on leaves. Previous studies also reported a strong correlation among the same fungal metrics and total breakdown rate of various leaf species (Gessner \& Chauvet, 1994; Maharning \& Bärlocher, 1996). This 
congruent pattern is consistent with the idea that aquatic hyphomycetes allocate a fairly constant fraction of their resource (leaf carbon) to reproduction (Chauvet \& Suberkropp, 1998). But, if so, mycelial biomass and spore production should be equally relevant in predicting the variation in microbial breakdown rate among streams. The fact that mycelial biomass leads to weaker correlations in our data set may indicate that ergosterol concentration is not an accurate marker of the biomass of fungi involved in leaf breakdown. Ergosterol concentration may indeed overestimate the biomass of living aquatic hyphomycetes because this compound is present in other groups of fungi occurring in submerged leaves (Bärlocher et al., 2008) and an appreciable amount can persist long after the death of fungal hyphae (Mille-Lindblom, Wachenfeldt \& Tranvik, 2004). For living aquatic hyphomycetes, spore production is therefore probably a more reliable indicator of fungal performance than ergosterol concentration.

Change in fungal diversity on leaves was not significantly related to any change in fungal performance (maximum spore production, maximum fungal biomass in leaves and microbial breakdown rate), suggesting that aquatic hyphomycete assemblages would provide complementary information on stream condition. The same basic idea has emerged from field surveys that failed to correlate leaf breakdown rate to stream fungal diversity (Bärlocher \& Graça, 2002; Pascoal, Cássio \& Marvanová, 2005a). Degradation of water quality may lead to a reduction of fungal diversity due to the loss of sensitive species, a pattern common to aquatic biota used routinely as bioindicators. However, unlike widespread indicators using macroinvertebrates or macrophytes, the identification of aquatic hyphomycetes is not easy. A comprehensive identification key is missing for this group, and many species cannot be reliably identified based on simple observations of preserved spores. Because the assessment of fungal diversity requires high taxonomic expertise and sometimes fungal isolation, research efforts should be directed toward the determination of indicator fungal species that are easily identifiable. For example, F. curvula is potentially a good candidate since there is evidence from our data and a previous survey (Solé et al., 2008) for the sensitivity of this common species to water pollution.

Irrespective of the ability of leaf-associated biota to detect stream impairment, total leaf breakdown rate still should be the central metric in multiparametric assessment based on leaf bags. Recently, some authors have questioned the relevance of this functional indicator, notably because of low statistical power (Hagen et al., 2006; Bergfur et al., 2007). We argue that this issue could be simply overcome by improving the methodology and statistical inferences in leaf bag experiments. First, because exposure time of leaf bags can greatly influence the estimation of the breakdown rate (Bergfur et al., 2007), it would be reasonable to use at least two or three sampling dates that cover the wide range of leaf decomposing stage. Secondly, one should always carefully select the most parsimonious model that describes the relationship between leaf mass remaining versus days or degree-days. For example, our observations and previous data (e.g. Richardson, Shaughnessy \& Harrison, 2004; Baudoin et al., 2008) indicate that the exponential model commonly used in previous studies should not be generalized.

Lastly, extreme caution should be exercised when calculating exponential decay rates by linear regression and when using ANCOVA to compare model parameters since the statistical assumptions are generally violated. The variance in leaf mass remaining tends to increase with time, and logarithm transformation further enhances the overdispersion of data as leaf mass remaining approaches zero. Consistent with our data (see Table S1), this mathematical process should lead to a larger bias in the estimation of $k_{\mathrm{c}}$-values than of $k_{\mathrm{f}}$-values, notably because leaf mass remaining in fine mesh bags is generally much higher and less variable than in coarse mesh bags at the end of experiments. Because overdispersion and heteroscedascity decrease statistical power, non-significant difference among sites according to ANCOVA should never be interpreted as the inability of leaf breakdown to discriminate among sites unless $P$-values are close to one. In this paper, we showed that nonlinear regression and generalized linear models are suitable methods for leaf breakdown data.

In summary, this study represents a first step towards a framework for the integration of aquatic hyphomycetes into a multiparametric assessment tool based on leaf bags as intended by Gessner \& Chauvet (2002). By compiling old and new data, we showed that aquatic hyphomycetes respond to widespread threats of stream ecosystems in a predictable manner. Spore production is a powerful indicator of fungal 
performance and stream condition, which could be easily incorporated into further studies. Moreover, it is clear that more data are needed on the response of aquatic hyphomycetes to different levels of eutrophication, different forest practices and other types of perturbations. We urge stream ecologists interested in leaf breakdown to consider leaf-associated fungi, notably because aquatic hyphomycetes, unlike many structural indicators that have been considered so far, occur predominantly in small streams for which specific assessment tools are required (Meyer et al., 2007). Meanwhile, it is crucial that mycologists explore more fundamental questions such as the influence of abiotic factors and biotic interactions on aquatic hyphomycete diversity and functions, and that they provide comprehensive identification keys to the scientific community.

\section{Acknowledgments}

We are indebted to Didier Lambrigot and Sophie Manzi for invaluable technical assistance, Jean-Marc Bonzom for the determination of heavy metals in water, and John Richardson for financial support to AL while writing this paper. We thank Mark Gessner, Mark Langan, Scott Tiegs and Guy Woodward for stimulating discussions about compilation of literature data and meta-analysis during a workshop held in Kastanienbaum. Comments from two anonymous reviewers improved the manuscript. This research was supported by the EU Commission (Rivfunction: contract EVK1-CT-2001-00088).

\section{References}

Abel T.H. \& Bärlocher F. (1984) Effects of cadmium on aquatic hyphomycetes. Applied and Environmental Microbiology, 48, 245-251.

Adams D.C., Gurevitch J. \& Rosenberg M.S. (1997) Resampling tests for meta-analysis of ecological data. Ecology, 78, 1277-1283.

Allan J.D. \& Flecker A.S. (1993) Biodiversity conservation in running waters. BioScience, 43, 32-43.

APHA (1998) Standard Methods for the Examination of Water and Wastewater, 20th edn. American Public Health Association, Washington, D.C.

Bärlocher F. (1992) The Ecology of Aquatic Hyphomycetes. Springer-Verlag, Berlin.

Bärlocher F. \& Graça M.A.S. (2002) Exotic riparian vegetation lowers fungal diversity but not leaf decomposition in Portuguese streams. Freshwater Biology, 47, 1123-1136.

Bärlocher F., Seena S., Wilson K.P. \& Williams D.D. (2008) Raised water temperature lowers diversity of hyporheic aquatic hyphomycetes. Freshwater Biology, 53, 368-379.

Baudoin J.M., Guérold F., Felten V., Chauvet E., Wagner P. \& Rousselle P. (2008) Elevated aluminium concentration in acidified headwater streams lowers aquatic hyphomycete diversity and impairs leaf-litter breakdown. Microbial Ecology, in press. Doi: 10.1007/ s00248-007-9344-9

Bergfur J. (2007) Seasonal variation in leaf-litter breakdown in nine boreal streams: implications for assessing functional integrity. Fundamental and Applied Limnology/Archiv für Hydrobiologie, 169, 319-329.

Bergfur J., Johnson R.K., Sandin L. \& Goedkoop W. (2007) Assessing the ecological integrity of boreal streams: a comparison of functional and structural responses. Fundamental and Applied LimnologyArchiv für Hydrobiologie, 168, 113-125.

Bermingham S., Maltby L. \& Cooke R.C. (1996) Effects of a coal mine effluent on aquatic hyphomycetes. II. Laboratory toxicity experiment. Journal of Applied Ecology, 33, 1311-1321.

Chaffin J.L., Valett H.M., Webster J.R. \& Schreiber M.E. (2005) The influence of elevated arsenic concentrations on organic matter processing in an Appalachian headwater stream. Journal of the North American Benthological Society, 24, 553-568.

Chamier A.-C \& Tipping E. (1997) Effects of aluminium in acid streams on growth and sporulation of aquatic hyphomycetes. Environmental Pollution, 96, 289-298.

Chauvet E. \& Suberkropp K. (1998) Temperature and sporulation of aquatic hyphomycetes. Applied and Environmental Microbiology, 64, 1522-1525.

Cheng Z.L., Andre P. \& Chiang C. (1997) Hyphomycetes and macroinvertebrates colonizing leaf litter in two Belgian streams with contrasting water quality. Limnetica, 13, 57-63.

Covich A.P., Austen M.C., Bärlocher F. et al. (2004) The role of biodiversity in the functioning of freshwater and marine benthic ecosystems. BioScience, 54, 767-775.

Duarte S., Pascoal C., Alves A., Correia A. \& Cássio F. (2008) Copper and zinc mixtures induce shifts in microbial communities and reduce leaf litter decomposition in streams. Freshwater Biology, 53, 91101.

Dudgeon D., Arthington A.H., Gessner M.O. et al. (2006) Freshwater biodiversity: importance, status, and conservation challenges. Biological Reviews, 81, 163-182. 
Ferreira V. \& Graça M.A.S. (2006a) Do invertebrate activity and current velocity affect fungal assemblage structure in leaves. International Review of Hydrobiology, 91, 1-14.

Ferreira V., Gulis V. \& Graça M.A.S. (2006b) Wholestream nitrate addition affects litter decomposition and associated fungi but not invertebrates. Oecologia, 149, 718-729.

Gessner M.O. \& Chauvet E. (1994) Importance of stream microfungi in controlling breakdown rates of leaf litter. Ecology, 75, 1807-1817.

Gessner M.O. \& Chauvet E. (2002) A case for using litter breakdown to assess functional stream integrity. Ecological Application, 12, 498-510.

Gessner M.O., Bärlocher F. \& Chauvet E. (2003) Biomass, growth and sporulation of aquatic hyphomycetes. Fungal Diversity Research Series, 10, 127-158.

Graça M.A.S., Pozo J., Canhoto C. \& Elosegui A. (2002) Effects of Eucalyptus plantations on detritus, decomposers and detritivores in streams. The Scientific World, 2, 1173-1185.

Grattan R.M. \& Suberkropp K. (2001) Effects of nutrient enrichment on yellow poplar leaf decomposition and fungal activity in streams. Journal of the North American Benthological Society, 20, 33-43.

Guimarães-Soares L., Felíciab H., Bebiannob M.J. \& Cássio F. (2006) Metal-binding proteins and peptides in the aquatic fungi Fontanospora fusiramosa and Flagellospora curta exposed to severe metal stress. Science of the Total Environment, 372, 148-156.

Gulis V. \& Suberkropp K. (2003) Leaf litter decomposition and microbial activity in nutrientenriched and unaltered reaches of a headwater stream. Freshwater Biology, 48, 123-134.

Gulis V., Ferreira V. \& Graça M. (2006) Stimulation of leaf litter decomposition and associated fungi and invertebrates by moderate eutrophication: implications for stream assessment. Freshwater Biology, 51, 1655-1669.

Hagen E.M., Webster J.R. \& Benfield E.F. (2006) Are leaf breakdown rates a useful measure of stream integrity along an agricultural landuse gradient? Journal of the North American Benthological Society, 25, 330-343.

Hedges L.V., Gurevitch J. \& Curtis P (1999) The metaanalysis of response ratios in experimental ecology. Ecology, 80, 1150-1156.

Hieber M. \& Gessner M.O. (2002) Contribution of stream detritivores, fungi, and bacteria to leaf breakdown based on biomass estimates. Ecology, 83, 1026-1038.

Krauss G., Bärlocher F. \& Krauss G.-J. (2003) Effects of pollution on aquatic hyphomycetes. Fungal Diversity Research Series, 10, 211-230.
Krebs C.J. (1999) Ecological Methodology, 2nd edn. Addison-Welsey Educational Publishers, Inc., New York.

Laitung B. \& Chauvet E. (2005) Vegetation diversity increases species richness of leaf-decaying fungal communities in woodland streams. Archiv für Hydrobiologie, 164, 217-235.

Laitung B., Pretty J.L., Chauvet E. \& Dobson M. (2002) Response of aquatic hyphomycete communities to enhanced stream retention in areas impacted by commercial forestry. Freshwater Biology, 47, 313324.

Lecerf A., Dobson M., Dang C.K. \& Chauvet E (2005) Riparian plant species loss alters trophic dynamics in detritus based-stream ecosystems. Oecologia, 146, 432442.

Lecerf A., Usseglio-Polatera P., Charcosset J.Y., Bracht B. \& Chauvet E. (2006) Assessment of functional integrity of eutrophic streams using litter breakdown and benthic macroinvertebrates. Archiv für Hydrobiologie, 165, 105-126.

Lecerf A., Patfield D., Boiché A., Riipinen M., Chauvet E. \& Dobson M. (2007) Stream ecosystems respond to riparian invasion by Japanese knotweed (Fallopia japonica). Canadian Journal of Fisheries and Aquatic Sciences, 64, 1273-1283.

Lindsey J.K. (1997) Applying Generalized Linear Models. Springer, New York.

Maharning A.R. \& Bärlocher F. (1996) Growth and reproduction in aquatic hyphomycetes. Mycologia, 88, $80-88$.

Malmqvist B. \& Rundle S. (2002) Threats to the running water ecosystems of the world. Environmental Conservation, 29, 134-153.

Mesquita A., Pascoal C. \& Cássio F (2007) Assessing effects of eutrophication in streams based on breakdown of eucalypt leaves. Fundamental and Applied LimnologyArchiv für Hydrobiologie, 168, 221230.

Meyer J.L. (1997) Stream health: incorporating the human dimension to advance stream ecology. Journal of the North American Benthological Society, 16, 439-447.

Meyer J.L., Strayer D.L., Wallace J.B., Eggert S.L., Helfman G.S. \& Leonard N.L. (2007) The contribution of headwater streams to biodiversity in river networks. Journal of the American Water Resources Association, 43, 86-103.

Mille-Lindblom C., Wachenfeldt E.V. \& Tranvik L.J. (2004) Ergosterol as a measure of living fungal biomass: persistence in environmental samples after fungal death. Journal of Microbiological Methods, 59, 253262.

Mille-Lindblom C., Fischer H. \& Tranvik L.J. (2006) Antagonism between bacteria and fungi: substrate 
competition and a possible trade-off between fungal growth and tolerance towards bacteria. Oikos, 113, 233242.

Niyogi D.K., Lewis W.M. \& McKnight D.M. (2001) Litter breakdown in mountain streams affected by acid mine drainage: biotic remediation of abiotic controls. Ecological Application, 11, 506-516.

Pascoal C. \& Cássio F. (2004) Contribution of fungi and bacteria to leaf litter decomposition in a polluted river. Applied and Environmental Microbiology, 70, 1-7.

Pascoal C., Pinho M., Cássio F. \& Gomes P. (2003) Assessing structural and functional ecosystem condition using leaf breakdown: studies on a polluted river. Freshwater Biology, 48, 2033-2044.

Pascoal C., Cássio F. \& Marvanová L. (2005a) Anthropogenic stress may affect aquatic hyphomycete diversity more than leaf decomposition in a low-order stream. Archiv für Hydrobiologie, 162, 481-496.

Pascoal C., Cássio F., Marcotegui A., Sanz B. \& Gomes P. (2005b) Role of fungi, bacteria, and invertebrates in leaf litter breakdown in a polluted river. Journal of the North American Benthological Society, 24, 784-797.

Pozo J., Basaguren A., Elósegui A., Molinero J., Fabre E. \& Chauvet E. (1998) Afforestation with Eucalyptus globulus and leaf litter decomposition in streams of northern Spain. Hydrobiologia, 373374, 101-109.

Raviraja N.S., Sridhar K.R. \& Bärlocher F. (1998) Breakdown of Ficus and Eucalyptus leaves in two organically polluted streams in India: fungal diversity and ecological functions. Freshwater Biology, 39, 537-545.

Richardson J.S., Shaughnessy C.R. \& Harrison P.G. (2004) Litter breakdown and invertebrate association with three types of leaves in a temperate rainforest stream. Archiv für Hydrobiologie, 159, 309-325.

Romaní A., Fischer H., Mille-Lindblom C. \& Tranvik L.J. (2006) Interactions of bacteria and fungi on decomposing litter: differential extracellular enzyme activities. Ecology, 87, 2559-2569.

Rosenberg M.S., Adams D.C. \& Gurevitch J. (2000) MetaWin. Statistical Software for Meta-Analysis. Version 2.0. Sinauer Associates, Sunderland, MA.

Solé M., Fetzer I., Wennrich R., Sridhar K.R., Harms H. \& Krauss G. (2008) Aquatic hyphomycete communities as potential bioindicators for assessing anthropogenic stress. Science of the Total Environment, 289, 557-565.

Sridhar K.R., Krauss G., Bärlocher F., Raviraja N.S., Wennrich R., Baumbach R. \& Krauss G.-J. (2001) Decomposition of alder leaves in two heavy metal polluted streams in Central Germany. Aquatic Microbial Ecology, 26, 73-80.

Suberkropp K. (1998) Effect of dissolved nutrients on two aquatic hyphomycetes growing on leaf litter. Mycological Research, 102, 998-1002.

Suberkropp K., Michelis A., Lorch H.J. \& Ottow J.C.G. (1988) Effect of sewage treatment plant effluents on the distribution of aquatic hyphomycetes in the River Erms, Schwäbische Alb, F.R.G. Aquatic Botany, 32, 141-153.

Thompson P.L. \& Bärlocher F. (1989) Effect of pH on leaf breakdown in streams and in the laboratory. Journal of the North American Benthological Society, 8, 203-210. 